\title{
Revenge and Vengeance in Shakespeare's Hamlet: A Study of Hamlet's Pursuit and Procrastination Regarding Revenge
}

\author{
Farhana Haque, M.A \\ Department of English and Humanities UniversityMohakhali, Dhaka Bangladesh
}

\begin{abstract}
Shakespeare was the phenomenal writer of Elizabethan era. Among his many greatest writing pieces, Hamlet was one of his most famous work. If we proceed to elucidate the play Hamlet, then we willsee there were three significant plots which has been presented with great importance. The main revenge plot and two othersub plots including the romance between Hamlet and Ophelia and the looming war with Norway. With these three significant plots Hamlet has dealt with procrastination, because the revengewas not done until the final scenes. However, Shakespeare did depict the direct reference to the traditionwith the play within play. For doing such, he did presentan Italian Picarro play called " The murder of Gonzago". In order to establish the true justice of Hamlet's father's murder, Hamlet attempted todecorate that Italian play with grim tenacity, he was very adamant to catch the real culprit of his father's death. To accomplish this hard task, Hamlet became slow and ponderedover many things. In this way Hamlet was slowin the process of taking revenge and as a result some other deaths has been taken place, such unnecessary deaths were the deaths of Polonius, Laertes, Ophelia, Gertrude, Rosencrantz and Guildenstern. To shed the highlight of Hamlet's inability of taking revenge on time, Shakespeare has exhibited a number of other characters who were capable of taking resolute and determined revenge as per their requirements. For examples, Fortinbrashas travelled from many miles to take revenge of his father's murder and ultimately he gothis desired success in conquering Denmark. Another character Laertes did plot against Hamlet to kill him in order to take revenge of his father Polonius's murder, and towards the end of this novel Laertes also got success in killing Hamlet by the poisonous sword. As a whole the predominant goal of this paper is to exhibit Hamlet as a revenge play where all other incidents of revenge has been incorporated brilliantly by Shakespeare.
\end{abstract}

Keywords: Adultery, Bloodshed, Murder, procrastination, Revenge

\section{I.INTRODUCTION}

William Shakespeare was one of the discreet playwright among the other playwrights of his time and also beyond of that. He has been portrayed his notable workHamletwith new dimension to his genre, the genre which hasreached to the zenith of its exclusive nature. Shakespeare's Hamletwas enriched the domain of revenge play during the Elizabethan era, and was first published in 1603.As a revenge play Hamlet did follow every steps of acceptable elements to classify it as a credible revenge play quite certainly. To make the revenge play as successful, Shakespeare became influenced bySophocles, Euripides and other Greek writers writing style and their ostentation of making a true revenge play. Besides all of them, Hamletwasattracted by the Senecan play The Spanish Tragedy which hasproved as a great revenge play of all time and era. However, Shakespeare's Hamletrepresented its story ascomplex and a concoctation of many themes. Revenge was one of the first and foremost theme in Hamlet. To some extent it has been adopted the dramatic conventions of revenge tragedy, where revenge was proved to be the most popular theme for Elizabethan play.The Elizabethan spectator's demands were centred with the depiction of vengeance inside of the play where there will be wild justice, the duty of vengeance should be considered as a pious duty upon the next kin. Moreover, all the victims should go directly to hell for burning and it should be for eternity. And after fulfilling all those criteria, a revenge play should be called as a great revenge play towards the Elizabethan people. Moreover,Hamletconsidered as a revenge play which hasfascinated by the frameworks of Senecan revenge tragedy. But Shakespeare did instilmany other notable themes of human condition, social teaching, the appearance of ghost as a moral injunction, and the ethics of revenge. These all significant themes were takenas the well acclaimed themes of Elizabethan revenge play where as a play Hamlet did cover all the areas which was necessary for presenting a revenge play of Shakespeare. From the Elizabethan era to $21^{\text {st }}$ century, the audience of Hamletactually has been mesmerized by the magnificent and conjuring ability of revenge play. 


\section{THE THEME REVENGE REPRESENTS THE CENTRAL ISSUE IN THE NOVEL HAMLET}

Shakespeare's Hamlet has been written based on the concept of revenge. This play was the exampleof long and tragic conflict between Hamlet and Claudius. Along with the revenge, there werethe traces of other forces to fuel the main theme in the form of suspense, climax and the catastrophe. All these things became visible especially to accomplish the revenge for Hamlet's father's murder case. With this main plot, Shakespeare did instil another sub-plot of taking revenge. Laertes, who was the another revenge seeker person in the play. He was also adamant to take revenge of his father Polonius's murder. In order to do that Laertes was occupied by the vengeance mood.

\section{THE GHOST'S APPEARANCE TO HAMLET IN ORDER TO INFORM ABOUT HIS FATHER'S MURDERER}

A.C Bradley said about the ghost appearance in the play Hamlet,

" The ghost In Hamlet strikes the imagination as the representation of the hidden power, the messenger of the divine justice upon the expatiation of offences"

It is to be said that, in revenge play the appearance of ghost is a significant part to inform about the wicked persons to the hero of the story. The ghost was the advisor of taking revenge and therefore in Hamlet the ghost like figure has given the unknown information about king Hamlet's murder, the ghost told that the murderer was no one but his own brother Claudius and told his son to take revenge against him. In Shakespeare's Hamlet, the opening scene was the most eeriest, full with enigmatic environments and shrouded with frightening moments. The ghost of king Hamlet, the late king of Denmark, has been manifested like a shadowy appearance, seemed like to wear his royal dress and embellished with armour. At first Horatio saw the ghost of late king Hamlet and he didn't able to believe in his own eyes and therefore he was dumbstruck. Two times the ghost did appear on the same place while Horatio asked two questions for two times to that shadowy existence but no reply came from the ghost. Later the news of ghost appearance reached to Hamlet. The real tension of the play becamestarted when the ghost of the late king told Hamlet about his murderer. The ghost told to Hamlet that it was his own brother Claudius who did kill him actually. From that time Hamlet wasdetermined and decided to take revenge on his uncle Claudius. Hamlet did concentration and started to ponder on his goal of taking revenge. He was having the strong tenacity to kill Claudius as he usurped the throne of his father unlawfully whereas the general people of the kingdom had no clue about this cruel truth. The ghost also informed Hamlet that he will be the one who can take revenge on the murderer and that's why Hamlet felt importance to take revenge with full of his consent.

"And so i am revenged. That would be scanned: A villain kills my father, and for that, i his sole son, this same villain send to heaven". ( Act III, Scene iii).

These words of Hamlet has been created thezeal of determination for taking revenge, and simultaneously the spectators of Hamlet became more curious to know that what will happen in next stages of Hamlet's revenge motif

\section{PSYCHOLOGICAL CONFLICTS EVOLVES IN THE MIND OF HAMLET}

The psychological conflicts were the most striking things in Hamlet's mind. And those conflicts has been started by delaying to take revenge against Claudius. Hamlet was actually having the problems of indecision. He did think everything very critically, there he has chose to kill Claudius in an indirect way rather than direct way. In order to prove that Claudius was the actual culprit, Hamlet haslaunched an Italian drama 'Gonzago 'with the same story line of his father's murder case in order to see the reaction of his uncle Claudius. He was been so alert and sensitive to accomplish the task of killing Claudius, which was his first conflict with his own inner self. Hamlet's moral conflict got appeared by his plot of attempting suicide. As he was perplexed that his own uncle did murder his father and at the same time his mother hasmarried with that murderer Claudius. But after all he has to take revenge which made him fall into despair and in extreme moral dilemma as his inner heart didn't want to deal with all these incredibly hard and risky steps.

"To be or not to be, that is the question: whether "tis nobler in the mind to suffer the slings and arrows of outrageous fortune or to take arms against a sea of trouble and by opposing end them".( Act III, Scene i).

These significant lines were attached with Hamlet's deep contemplation about life and after life's situation. These remarkable lines has been delivered by Hamlet to convey the readers about his inner conflict due to the fear of the after life. In Hamlet's thinking, it is a man who wasassigned to bear the unfortunate belongings of life and thus fear of what will come afterlife and the fear of unknown things. Towards to end of this play Hamlet has thrown the idea of suicide. The life after death there will be the unsewn realm, from where no one shall return. These doctrine about the life after death made him thoughtful, puzzled and worried. 
" we would fardels bear, to gust and swat under a weary life, but that the dread of something after dath,the undiscovery country, from. Whose bourn no traveller returns, puzzles, the will, and made us rather bear those ills. We have been fly to others that we know not of". ( Act III, Scene i)

Besides the conflict of inner self, Hamlet has found out another conflict as an outward conflict. When The Prince Hamlet has been known about his mother' remarriage with Claudius, he becamefurious and did commit to take another revenge upon his mother. On the other hands, the ghost ofhis father remarked that, his wife Gertrude doesn't need any punishment through killing. The ghost elucidatedthat, Gertrude's own conscience one day will devour her soul and that will be the most devastating plight in her life, which would be enough for her. “Leave her to heaven, and to those thrones that in her bosom lodge to prick and sting her". (Act I, Scene v ).

After knowing the ideologies of mental punishment to Gertrude, Hamlet did show dispute regarding the ideologies of his father's ghost. He actually felt that the explicit activities of taking revenge will be the one and onlyway to punish her. In that way Hamlet has marched towards thisrisky task andconfronted his mother. Beinga scintillating person William Shakespeare beautifully exhibited Hamlet's conflictsas the symbols of human 's criticalconflicts, with the references of different human nature, the compatibility between one person with the other. Hamlet was portrayed as a character of human's ingrained and innate qualities. He has been carried out the instincts of doing mistakes, having anger, and longing to punish the evil doers and also unaware of his own misfortunes. Being an indescribable talent of human psychology, Shakespearehas invented the philosophy of human's conflicts against their mind and tried to bring a change between men and women who were treated unfairly. Hamlet's inner heart got awed by seeing his uncle's behaviours and feelings which has been occupied with his mother. Hamlet became emotionally shattered and did contemplate about his father's early departure from this world. He then made a solemn pledge that, his inner soul will get peace only when he could get success to take revenge on the murderer Claudius. Hamlet also knew that no one in the kingdom has any idea of his father's killing story, thus he got the platform to perform the tough task of killing Claudius. All these things were surely the notable and pertinent conflicts in Hamlet's mind which has been presented beautifullyby Shakespeare.

\section{HAMLET PROVES AS A PLAY OF BLOODSHED, ADULTERY, CORRUPTION AND DEATH}

Shakespeare's Hamlet was known as a world famous revenge tragedy of all time. The enthralling plots of Claudius'scruel intention tomurder the king Hamlet and to got married with his wife made the greatest play Hamlet as a play of fierce motif of revenge. The seeds of bloodshed, adultery, corruption and death has been planted soon after the ghost did convey the actual information about the king Hamlet's murder. Here we can say the appearance of ghost hascreated the sensation inside of the story of Hamlet. The murder of king Hamlet was more than a mysterious event which has shown the corrupted mind of Claudius, as he usurped the king Hamlet's throne illegally and by force. The traces of adultery came soon after Gertrude did marry with Claudius. This was her second marriage with her late husband's brother. There actually lied more than enough proof of Gertrude's tainted mind. She was a kind of disgusting woman who only used to think about her own happiness and didn't even think of her son while she did marry with Claudius. This kind of selfish attitudes of Gertrude has been taken the play Hamlet towardsthe unlawful relationship. Hamlet was furiously angry with his mother as she did marry with Claudius, Hamlet's father's own brother. He remarked that what his mother has done was a very shameful for a woman to do and therefore people will have no trust or respect for her. He also said that even God will be angry with her. He asked of Gertrude with desperation:

" ... go not to my uncle's bed./ ... / ... Refrain tonight. /And that shall lend a kind of easiness/ To the next abstinence, the next more easy;"( Act III, scene iv, 160, 166-68).

After seeing the attitudes of selfishness, Hamlet did trace the concept to think something disgusting about his mother. For Hamlet women just wear make up to hide their age, the women can only deceive men. By the end of the play, Hamlet got the real meaning aboutlife, which was appeared to him as his indoctrination. Life means to grab the power, to deal with the vicious things like murder, corruption and adultery, hence Hamlet has been considered those elements as the reality of life.

\section{HAMLET'S BECOMES FAILURE REGARDING THE LOVE AFFAIR WITH OPHELIA}

Ophelia was basically the loyal character in Hamlet. Her dependence was fully on her father and brother. She always tried to obey her father and brother whatever they asked her to do. Ophelia loved Hamlet but suddenly stopped to keep any contact with him because her father and brother have told her to do so. But, Hamlet was a promising and thriving young man, and he could chose a certainly happy and safe life ahead with Ophelia. As he loved Ophelia; and could have a very happy married life with her. But, he was in quest into such a complicated situation from where he had to choice except to take revenge of his father's murder. In the time of their love affair Polonius wanted Ophelia to return all the letters that Hamlet gave her; and she instantly agreed 
to do that. By knowing that Ophelia has been rejected him, then he becamedisappointed about females nature. He was frustrated and traumatized by his mother's remarriage to his uncle with in a few days after her first husband's death. Hamlet was not only felt ruined but, he was deeply embarrassed by Gertrude's act of getting married so quickly. And, her dishonest attitude towards her dead husband made Hamlet hate her. Hamlet's hatred was fathomless that he has removed his respect and faith on women in general. And therefore he though that women can do anything and they are able to do all the terrible deeds. Besides of Hamlet's mother's selfish nature, he was shocked by seeing Ophelia's ungrateful love towards him. He truly loved Ophelia, he wrote a letter where he didremark such beautiful words for Ophelia,

" Doubt thou the stars are fire, Doubt that the sun doth move,. Doubt truth to be a liar,. But never doubt I love"(Act II, Scene II)

Above lines proved that Hamlet's love was very true and deep towards Ophelia and he wanted to be like this forever. But her rejection to himhas created the deepest and fixed negativity about women. To him every woman is a potential whore and that is why he gives advice to Ophelia:

"Get thee to a nunnery. Why, wouldst thou be a I breeder of sinners?". ( Act III, Scene I).

His misogynistic concept was also very intense when he did show his philosophy about the reality of human in the graveyard scene, he said that he wanted to remind the 'young lady',here 'young lady'means the entire female race, that the female race would also share the same fate as the skulls of the graveyard no matter how beautifully and artistically she(female race) does paint her cheeks now. He also said that after death she too would transferred in to a ordinary skull and some bones with no beauty or ostentation.

\section{NEXUS OF MURDERERS WITH THEIR BRUTAL INSTINCT OF KILLING}

In the play Hamlet, there has been happened a number of murders and with every murder case there was the presence of revenge mentality. At first the king Hamlet was being murdered by Claudius in order to take the power. In fact this was the foundation of the massive killing concepts in the characters of Hamlet. The queen Gertrude was died after she has taken the poisonous goblet. The king Claudius also died by the poisonous sword of Hamlet. On that same day Laertes also died by that same poisonous sword. Finally Hamlet died by the poisonous sword of Laertes in the time of combating with him. All thesebrutal murdersdid takeplace with the trace of insanity and the notion of avenging naturewhichmade the entire play became chaotic and full of galumph movements. As a whole the play Hamlet was considered as a play of revenge from all its possible ways.

\section{HAMLET'S PROCRASTINATION OF TAKING REVENGE}

Hamlet was the man who was bound to kill Claudius in order to take revenge of his father's murder. But he didn't able to bring that into action because of reasons after reasons and because of his delays. Hamlet was actually considered to be an indecisive person who always used to think much but act too little. In this play Hamlet diddepict his nature of delaying from thefirst scene, regarding the ghost matter. The ghost played a very important role in the play. Since there was no eyewitness of the King's death, hence nobody knew that he was killed. Therefore, the ghost will be the only source from where the information can be found. And, Hamlet's reaction to the ghost was different from other revenge tragedy heroes because the other protagonists in other revenge plays used to believe in the ghost's story immediately. But in this play Hamlet didquestions the very existence of the ghost and thought of the possibility that it could be an evil spirit:

... the spirit that [ have seen May be the devil; and the devil hath power

To assume a pleasing shape; yea, and perhaps

Out of my weakness and my melancholy,

As he is very potent with such spirits,

Abuses me to damn me. (Act II, Scene ii, 552-556)

Hamlet didn't easily believe the ghost. Therefore, he wanted a certain conformation of the ghost's story about the death of his father. The another situation of making the revenge process delay, was that Hamlet decided to arrange a drama by creating the same story of his father's murder. After seeing the group of actors Hamlet did plans to stage a play called the "Themurder of Gonzalo" to verify the story of his father's murder as narrated by the ghost. He thought that by observing the reaction of the king he will be able to decide whether he is real murderer or not.

"The play's the thing / Wherein I'll catch the conscience of the King (Act II, Scene ii, 557-58).

Again Hamletdelayed of killing Claudius when he was praying. Hamlet thought it would be a great mistake if he kill Claudius now as he was in prayer. Hamlet hascontemplated over this matter and decided that Claudius will go to heaven if he kill him in a position of praying towards God. Hamlet thenlost the third chance of taking revenge against Claudius when he did kill Polonius accidently as he thought Polonius as Claudius. After this unfortunate tragic murder Hamlet has been sent to England. And as a result his revenge process got delayed. In his trip to England he made a strong resolute to come back to his country with full determination and energy for 
taking revenge. But actually he did procrastination for which he had to pay by giving his life towards the end of this play Hamlet.

\section{FORTINBRAS'S ENTRANCE IN TO DENMARK ANDTHE MOMENT OF CAPTURING THE KINGDOM}

The Norwegian prince, Fortinbras purposefullyentered in Denmark with his ambassadors from England. At first he saw Rosencrantz and Guildenstern as dead. After that he got shocked to see the devastating sight of the entire royal family who were laid sprawled on the floor with bloodshed. Fortinbras actually came to take revenge of his father's murder but after knowing the tragic story of the entire royal family he got dumbstruck. Later Horatio told him the whole tragic story and at the end of the play Fortinbras gave order to show respect to Hamlet in proper way. Therefore Hamlet was carried away in a manner of befitting a fallen solider. Finally Fortinbrashas captured the kingdom of Denmark and then the cruel history of it came to an end.

\section{CONCLUSION}

William Shakespeare's Hamlet was an example of perfect and witty revenge play. The first part of this play wasmade with the revenge motif and it has been carried out till the end as well. Hamlet was actually convinced by his father's ghost and he got the tenacity to take revenge upon Claudius, Hamlet's father's murderer. He finally understood that there will be no fair justice, and as a result he has to take the law in his hands. For accomplishing this hard and risky task of revenge, Hamlet got frazzled from his mind and as well as he was suffering from the symptom of indecision. In the same time Hamlet did use to keep connection with the audience by his famous and greatest soliloquies including the famous "To be or not to be..." ( Act III, Scene i) Hamlet got infuriated by seeing his mother with the culprit Claudius which was the most striking moment in the play. In this play there also came the controversial mad condition of Hamlet and also the mad scene of Ophelia when she came to knowabout her father's death and Hamlet whowas also sent to England. These two events made Ophelia totally shocked and frustrated therefore she did suicide by drowning in the river. At the end of the play the audience hasseen the entire royal family became deceased and the whole kingdom got entered in to the edge of demolishing its past glory. Therefore the play Hamletwas considered as a total and absolute revenge play with tragedy.

\section{REFERENCES}

[1] Bradley, A. C. Shakespearean Tragedy: Lectures on Hamlet, Othello, King Lear, Macbeth. 2nd ed. London: Macmillan, 1905.

[2] William, Shakespeare. Hamlet. Ed. Philip Edwards. New Delhi: Cambridge University Press, 2000. 